\title{
PREPARATION OF AGGLUTINATING ANTISERA SPECIFIC FOR THE FLAGELLAR ANTIGENS OF PSEUDOMONAS AERUGINOSA
}

\author{
T. L. PITT \\ Division of Hospital Infection, Central Public Health Laboratory, Colindale Avenue, \\ London NW9 5 HT
}

\begin{abstract}
Summary. H-specific agglutinating sera to Pseudomonas aeruginosa were prepared by immunisation with partially purified flagella. The results of agglutination and immobilisation tests with rabbit sera prepared against the flagella of six $\mathrm{H}$-type strains showed that the sera had high titres and were $\mathrm{H}$ specific.

Cross-absorption tests revealed that one strain $(\mathrm{H}-3)$ possessed a distinct antigen not present in any of the others. Two groups of strains ( $\mathrm{H}-1, \mathrm{H}-2$ and $\mathrm{H}-5 ; \mathrm{H}-4$ and $\mathrm{H}-6$ ) each possessed a distinct major antigen. Members of these two groups could be distinguished by their minor antigens.
\end{abstract}

\section{INTRODUCTION}

Identification of the heat-stable somatic (O) antigens is widely used as a means of typing Pseudomonas aeruginosa (Habs, 1957; Verder and Evans, 1961; Lányi, 1966-67; Homma et al., 1970). Although the results are highly reproducible (Parker et al., 1976), some O groups constitute up to one-fifth of all strains encountered in clinical specimens.

Lányi (1970) showed that the heat-labile antigens of $P$. aeruginosa were heterogeneous, that at least two of them were flagellar, and that their detection could be used for the further subdivision of $O$ groups. The preparation of mutants of $P$. aeruginosa that lacked flagella, or pili (fimbriae), or both (Bradley and Pitt, 1974; Pitt and Bradley, 1975) made it possible to study separately the antibody response to these two classes of antigen and to develop a specific and convenient test for $\mathrm{H}$ antibody - the inhibition of the ability of the organism to migrate through nitrate agar.

The immunisation of rabbits with phenolised suspensions of a limited number of $P$. aeruginosa strains led to the identification of six $\mathrm{H}$-antigenic factors for which apparently $\mathrm{H}$-specific agglutinating sera could be prepared by suitable absorptions. However, later observations that these sera sometimes agglutinated field strains without immobilising them (Pitt, 1979) indicated that antibody against other heat-labile components might also be present in them. As a result, the practice of preparing sera with unheated 
whole cells was abandoned, and an alternative method of preparing sera with purified flagella was investigated. The development of these methods and the construction of an $\mathrm{H}$ serological scheme is now reported.

\section{MATERIALS AND METHODS}

Bacteria. The origin of the strains used for the production of $\mathrm{H}$ antisera is shown in table $\mathrm{I}$.

Culture media and solutions. Nutrient Broth No. 2 (Oxoid) was used throughout for liquid culture; agar $1 \%(\mathrm{w} / \mathrm{v})$ was added to make nutrient agar for plate culture, and agar $0 \cdot 25 \%(\mathrm{w} / \mathrm{v})$ ("soft agar") for motility tests. Sodium nitrate was added when appropriate to either broth or agar to a final concentration of $0.2 \%(\mathrm{w} / \mathrm{v})$. Incubation was for $18 \mathrm{~h}$ at $32^{\circ} \mathrm{C}$ unless otherwise stated.

Saline was aqueous $\mathrm{NaCl} 0.85 \%(\mathrm{w} / \mathrm{v})$, and phenol saline was saline with solid phenol added to a final concentration of $0.5 \%(\mathrm{w} / \mathrm{v})$. Phosphate-buffered saline, $p \mathrm{H} 7.4$ (PBS; $0.002 \mathrm{M})$ was prepared by dissolving tablets of PBS reagent (Dulbecco "A"; Oxoid) in distilled water.

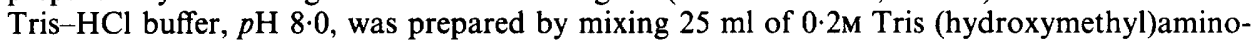
methane with $27.9 \mathrm{ml}$ of $0.1 \mathrm{M} \mathrm{HCl}$ and making up to $100 \mathrm{ml}$ with distilled water.

Pilusless mutants. Pilusless mutants of strain H-3 (strain PAO1) and H-4 (strain K) had been prepared previously (Bradley, 1972, 1973). Mutants of the other H-type strains listed in table I were selected with the following pilus-dependent phages by the method of Bradley (1973): strain H-1 with phage PO4 (Bradley, 1973); strain H-2 with phage M6 (Bradley and Pitt, 1974); strain H-5 with phage PO4; and strain H-6 with phage PP7 (Bradley, 1966). Mutants were examined in the electron microscope for the absence of pili and lyophilised.

Motility tests. The methods for the demonstration of motile bacteria in liquid culture and the selection of motile forms by culture in nitrate-containing agar in Craigie tubes were described by Pitt and Bradley (1975).

Selection of non-motile mutants. Logarithmic dilutions of a 4-h broth culture of a strain were made in broth and $0.1 \mathrm{ml}$ of the 1 in $10^{5}$ or 1 in $10^{6}$ dilution was spread over the surface of a nutrient-agar plate to give 10-20 colonies per plate. The plate was chilled at $4^{\circ} \mathrm{C}$ and $15 \mathrm{ml}$ of molten soft agar containing sodium nitrate at $45^{\circ} \mathrm{C}$ was poured rapidly over the surface. After incubation, colonies of non-motile bacteria were differentiated from "motile" colonies by the absence of a halo-like swarm.

Preparation of flagella. Six autoclavable polypropylene trays of dimensions $30 \mathrm{~cm} \times 25$ $\mathrm{cm} \times 5 \mathrm{~cm}$, covered with sterile aluminium foil, were each filled with $750 \mathrm{ml}$ of agar to a depth of c. $3 \mathrm{~cm}$. The agar surface was dried for $1 \mathrm{~h}$ at $37^{\circ} \mathrm{C}$ and $10 \mathrm{ml}$ of a $3-\mathrm{h}$ broth culture of the motile bacteria were spread over the surface. The excess fluid was removed and the trays were incubated at $25^{\circ} \mathrm{C}$ for $72 \mathrm{~h}$. The growth was harvested in phenol saline $(200 \mathrm{ml})$ and left to stand for $1 \mathrm{~h}$ in an ice bath. The suspension was homogenised in a pre-cooled stainless steel chamber

TABLE I

Origin and $O$-serological group of the H-serotype strains of Pseudomonas aeruginosa

\begin{tabular}{llcl}
\hline $\begin{array}{c}\text { H-serotype } \\
\text { strain }\end{array}$ & \multicolumn{1}{c}{$\begin{array}{c}\text { Original strain } \\
\text { designation }\end{array}$} & $\begin{array}{c}\text { O-serological } \\
\text { group (IATS)* }\end{array}$ & \multicolumn{1}{c}{ Reference } \\
\hline H-1 & Habs 1 & 1 & Habs (1957) \\
H-2 & PS M6† & 11 & Lindberg et al. (1963) (see Bergan, 1975) \\
H-3 & PAO1 (ATCC25247) & 16 & Holloway (1955) \\
H-4 & K (ATCC25102) & 6 & Bradley (1973) \\
H-5 & $74 / 13588$ & 3 & Isolated locally \\
H-6 & $74 / 12768$ & NT & Isolated locally \\
\hline
\end{tabular}

* International Antigenic Typing Scheme (see Bergan, 1975).

† Propagating strain for phage M6. It has no connection with the Pseudomonas maltophilia phage described by Moillo (1973) and also numbered M6. 
for $45 \mathrm{~s}$ at half speed in an Atomix (Measuring and Scientific Ltd, Crawley, Sussex) with a chamber capacity of $200 \mathrm{ml}$. The cells were removed by centrifugation twice at $16000 \mathrm{~g}$ for 45 min. The flagella and other small bodies were deposited at $40000 \mathrm{~g}$ for $2 \mathrm{~h}$ at $4{ }^{\circ} \mathrm{C}$ in a Spinco Model $\mathrm{L}$ preparative ultracentrifuge. The clear gelatinous pellet was gently dispersed in $10 \mathrm{ml}$ of Tris- $\mathrm{HCl}$ buffer and re-centrifuged at $40000 \mathrm{~g}$ for a further $2 \mathrm{~h}$. The final deposit was dispersed in $5 \mathrm{ml}$ of the same buffer and lyophilised.

The protein content of suspensions of flagella was determined by the method of Lowry et al. (1951) with bovine serum albumin as the standard. Carbohydrate was measured as total hexose by the anthrone-sulphuric acid method of Trevelyan and Harrison (1952) with glucose as the standard.

Preparation of antisera. Wistar albino rats (average weight $0.18 \mathrm{Kg}$ ) were used for experiments on the immunogenicity of flagella. They were aged 12 weeks at the first injection and blood samples were taken from the tail. Californian rabbits $(2.5-3.0 \mathrm{Kg})$ were used for the preparation of larger quantities of sera. Test bleeds of $5 \mathrm{ml}$ were obtained from an ear vein and animals were later bled out under anaesthetic by heart puncture.

Methods for the testing of sera by tray agglutination and absorption of agglutinin were described by Pitt and Erdman (1978). Slide agglutination tests were performed in the standard way.

Motility-inhibition test. Nine sterile 25-ml capacity screw-capped bottles were placed in a $50^{\circ} \mathrm{C}$ water-bath; $19.8 \mathrm{ml}$ of molten soft agar containing sodium nitrate $\left(\right.$ at $\left.50^{\circ} \mathrm{C}\right)$ was added to the first bottle and $10 \mathrm{ml}$ to each of the remaining bottles. To the first bottle, $0.2 \mathrm{ml}$ of undiluted $\mathrm{H}$ serum was added and gently mixed, $10 \mathrm{ml}$ of this serum dilution (1 in 100) was transferred to the second bottle and seven doubling dilutions of $10-\mathrm{ml}$ volumes were made. The ninth bottle without serum served as a control. A sterile glass cylinder $(50 \mathrm{~mm} \times 5 \mathrm{~mm})$ was placed in each bottle before the agar was cooled at $4{ }^{\circ} \mathrm{C}$ for $30 \mathrm{~min}$. Cultures were seeded into the cylinders and the tests were incubated. The highest serum dilution that inhibited the migration of the bacteria, observed by the absence of gas bubbles and opacity in the medium outside the tube, was termed the immobilisation titre of the serum.

Electron microscopy. The methods described by Bradley and Pitt (1974) were used.

\section{RESULTS}

\section{Immunogenicity of purified flagella}

Strain H-4 was used in preliminary experiments to determine the immunogenicity of flagella. Samples of lyophilised flagella of the pilus-less mutant were reconstituted at a concentration of $5 \mathrm{mg} / \mathrm{ml}$ in PBS. The protein content was calculated as $80-84 \%(\mathrm{w} / \mathrm{v})$ and the total carbohydrate as $6 \cdot 0-8.5 \%(\mathrm{w} / \mathrm{w})$ of the original preparation.

Immune response to a single dose of flagella. Three groups each of three rats were given single intravenous injections of constant volume $(0.2 \mathrm{ml})$ of flagellar preparations containing $0.025,0.25$ or $2.5 \mu \mathrm{g}$ of protein. The animals were bled 1 week after the injection and at weekly intervals for 3 weeks. A bleeding from a non-immunised rat served as a control to establish the level of naturally occurring antibody to flagella. Doubling dilutions of the sera were tested by slide agglutination with strain $\mathrm{H}-4 \mathrm{pil}^{-}$.

The agglutination titre of the control serum was less than 10; and the titres of the serum of each immunised rat within a group were identical. Fig. 1 shows the titres of agglutination plotted against time; the peak of antibody production was reached by the first week after the injection of flagella and there was a steady decline in agglutinin over the remaining weeks. The titres of the 


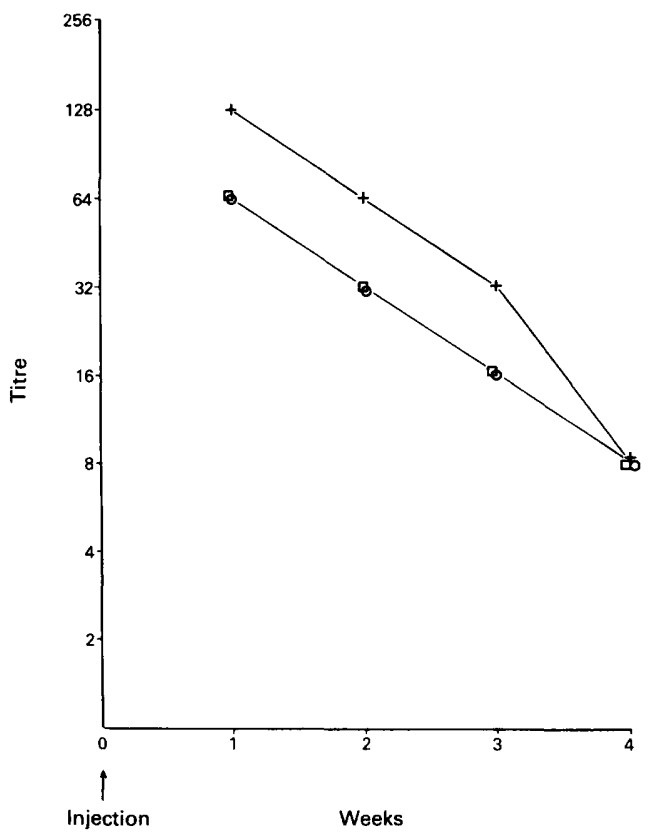

FIG. 1.-Serum-antibody titres of three groups of rats given single doses of $0.2 \mathrm{ml}$ of flagellar preparations containing $2.5 \mu \mathrm{g}(+-+) ; 0.25 \mu \mathrm{g}\left({ }^{-}\right)$); $0.025 \mu \mathrm{g}(\square-\square)$ of protein.

sera from rats given the largest dose were only twice as great (128 and 64) as the titres of the sera obtained from the group that had received a 100 -fold less concentrated antigen.

Immune response to increasing doses of flagella. Three rabbits of similar weight were each given a separate course of intravenous injections of constant volume ( $1 \mathrm{ml}$ ) of flagellar preparations containing increasing concentrations of protein (table II). The rabbits were bled on days 4, 7, 11, 14, 21 and 28 after the first injection and the sera were titrated in doubling dilutions and tested with

\section{TABLE II}

Experimental immunisation schedules of intravenous injections of increasing doses of Pseudomonas aeruginosa flagella in rabbits

\begin{tabular}{rlrr}
\hline \multirow{2}{*}{ Day } & \multicolumn{3}{c}{$\begin{array}{l}\text { Dose } \mu \mathrm{g} * \text { of protein given } \\
\text { on stated day to rabbit no. }\end{array}$} \\
\cline { 2 - 4 } & 1 & 2 & 3 \\
\hline 1 & $2 \cdot 5$ & 25 & 100 \\
5 & 5 & 50 & 200 \\
9 & 10 & 100 & 300 \\
13 & 20 & 200 & 400 \\
17 & 40 & 300 & 500 \\
22 & 80 & 400 & 600 \\
\hline
\end{tabular}

* Expressed as $\mu \mathrm{g}$ of protein per $\mathrm{ml}$ in constant volume $(1 \mathrm{ml})$ of inoculum. 
strain $\mathrm{H}-4$ pil $^{-}$by slide agglutination. The plot of the titres against time is shown in fig. 2.

The agglutination titres of the sera from each rabbit rose rapidly and reached their maximum by the 14th day after the first injection. Despite continued injections of larger doses of antigen, the titres subsequently remained almost static and in two cases fell by a single dilution. There was a substantial difference in the agglutinin response of each rabbit to the concentrations of flagellar antigen. The titre of the serum from the rabbit that had received an initial dose of $2.5 \mu \mathrm{g}$ of protein was eightfold lower than the titre of the animal immunised with an initial injection containing $100 \mu \mathrm{g}$ of protein.

Presence of $O$ antibody. The specificity of the three rabbit sera prepared above was determined by slide agglutination tests with a non-flagellate variant of strain $\mathrm{H}-4$ pil $^{-}$which was selected by the agar-overlay method.

The variant $\mathrm{H}-4 \mathrm{pil}^{-} \mathrm{fla}^{-}$was tested with dilutions of the fourth bleedings (14 days after the first injection) and the last bleeding (28 days) from each of the three rabbits. Antisomatic antibody was found only in moderate titre (40) in the fourth serum from rabbit no. 3 (H titre 2560), which had received the highest concentration of protein, and agglutinin was not detected in any of the

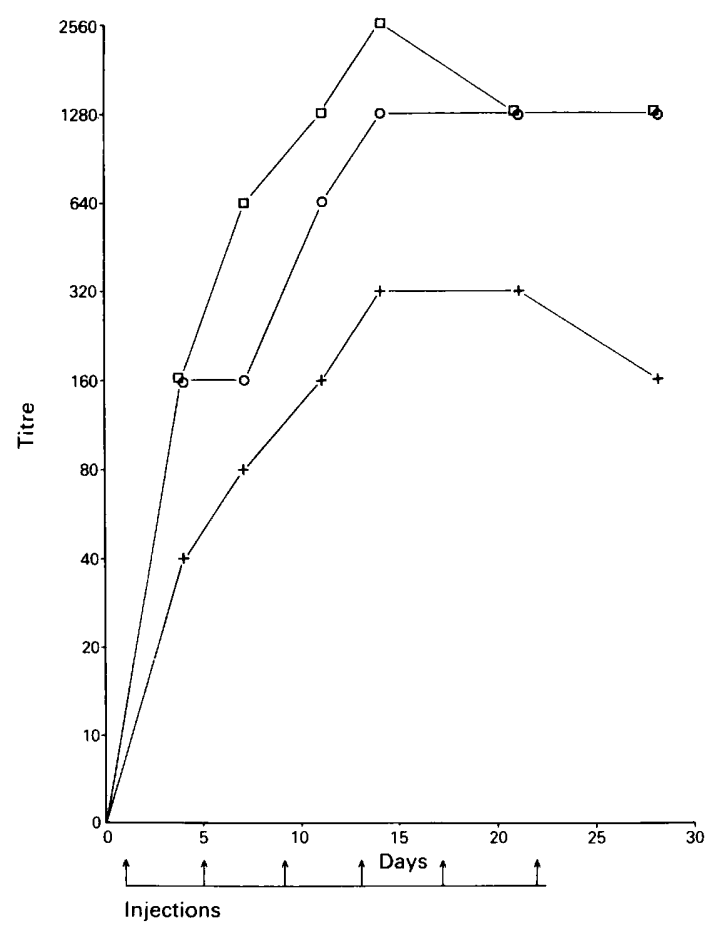

FIG. 2.-Serum-antibody titres of rabbits given increasing doses of flagellar preparations in a constant volume of $1 \mathrm{ml}$ (see table II). Protein concentration per $\mathrm{ml}$ of initial dose: $2 \cdot 5 \mu \mathrm{g}(+-++) ; 25 \mu \mathrm{g}$ $(\circ) ; 100 \mu \mathrm{g}(\square-0)$. 
sera from rabbit no. 1. The titre of the fourth bleeding of rabbit no. 2 was low (20) and this had dropped by one-half in the final serum.

\section{Antisera to H-type strains}

Suspensions of flagella were prepared from pilusless mutants of the H-type strains ( $\mathrm{H}-1$ to $\mathrm{H}-6)$; the carbohydrate content of each sample was less than $8 \%$ $(w / w)$. Antisera were raised in rabbits according to the schedule used for rabbit no. 2 (see table II).

The sera were tested by tray agglutination and by immobilisation with each of the homologous and all heterologous strains. The results (table III) show that all of the sera gave high homologous titres of agglutination and immobilisation $(>3000)$ but that only serum H-3 was specific. Cross reactions, in both tests, were at titres often of one quarter and sometimes one half of the homologous titre. Each type strain was immobilised by a homologous serum dilution of about one half of the agglutination titre but the endpoint of immobilisation was sometimes difficult to determine. In some tests, although serum dilutions had immobilised the mass of the culture, wisps of growth appeared to emanate from the original inoculum line. The titre was recorded as the highest serum dilution that completely immobilised the culture.

Somatic antibody in the sera was low; with the exception of serum $\mathrm{H}-2$, none of the sera agglutinated the homologous or heterologous non-motile variants at a dilution of above 1 in 50; the homologous somatic antibody titre of serum $\mathrm{H}-2$ was 100 .

Cross absorption of $H$ antisera. Each serum was absorbed separately with unheated suspensions of each of the heterologous strains that were agglutinated by the serum and re-tested by agglutination and immobilisation with

TABLE III

Agglutination and immobilisation in agar of H-type strains of Pseudomonas aeruginosa by homologous and heterologous $H$ antisera

\begin{tabular}{|c|c|c|c|c|c|c|}
\hline \multirow{2}{*}{$\begin{array}{l}\text { Serum } \\
\text { against } \\
\text { type } \\
\text { strain }\end{array}$} & \multicolumn{6}{|c|}{$\begin{array}{l}\text { Titre of agglutination (and immobilisation) } \\
\text { by the stated serum of the type strain }\end{array}$} \\
\hline & H-1 & $\mathrm{H}-2$ & $\mathrm{H}-3$ & $\mathrm{H}-4$ & H-5 & H-6 \\
\hline $\mathrm{H}-1$ & $\begin{array}{c}6400 \\
(3200)\end{array}$ & $\begin{array}{c}800 \\
(800)\end{array}$ & - & - & 1600 & - \\
\hline $\mathrm{H}-2$ & $\begin{array}{r}800 \\
(400)\end{array}$ & $\begin{array}{r}3200 \\
(3200)\end{array}$ & - & - & $\begin{array}{l}1600 \\
(800)\end{array}$ & $\begin{array}{c}400 \\
(200)\end{array}$ \\
\hline $\mathrm{H}-3$ & - & - & $\begin{array}{l}12800 \\
(6400)\end{array}$ & - & - & - \\
\hline $\mathrm{H}-4$ & - & - & - & $\begin{array}{l}12800 \\
(6400)\end{array}$ & - & $\begin{array}{c}6400 \\
(3200)\end{array}$ \\
\hline H-5 & $\begin{array}{c}3200 \\
(1600)\end{array}$ & $\begin{array}{l}1600 \\
(800)\end{array}$ & - & $\begin{array}{l}800 \\
(200)\end{array}$ & $\begin{array}{l}12800 \\
(6400)\end{array}$ & $\begin{array}{c}800 \\
(400)\end{array}$ \\
\hline H-6 & - & $\begin{array}{l}1600 \\
(800)\end{array}$ & - & $\begin{array}{c}3200 \\
(1600)\end{array}$ & - & $\begin{array}{c}12800 \\
(6400)\end{array}$ \\
\hline
\end{tabular}


these strains. Table IV shows that two sera, H-1 and H-4, absorbed with strains $\mathrm{H}-2$ and $\mathrm{H}-6$ respectively, did not exhibit cross reactions at a dilution of 1 in 100. However, the homologous titres of serum $\mathrm{H}-2$ absorbed with strain $\mathrm{H}-5$, H-5 absorbed with strain H-2, and H-6 absorbed with strain $\mathrm{H}-4$ were 4-, 8- and 16-fold respectively higher than the titre of cross reactions with a heterologous strain and therefore these sera needed only to be diluted above the heterologous titre to render them specific.

The results indicated that the flagellar antigens of strains $\mathrm{H}-1, \mathrm{H}-2$ and $\mathrm{H}-5$ were related. For example, the absorption of serum $\mathrm{H}-1$ with strain $\mathrm{H}-2$ slightly lowered the homologous titre and completely removed antibody to strain H-5. Moreover, when the same serum was absorbed with strain H-5, the homologous agglutination and immobilising titres were markedly reduced but the reaction with strain $\mathrm{H}-2$ was still evident. Strain $\mathrm{H}-1$ did not absorb homologous antibody from serum $\mathrm{H}-2$ or reduce the titre with strain $\mathrm{H}-5$ but the latter strain did remove antibody from this serum to strain $\mathrm{H}-1$. The cross reaction of serum $\mathrm{H}-2$ with strain $\mathrm{H}-6$ was not removed by strains $\mathrm{H}-1$ or $\mathrm{H}-5$ and the corresponding absorption with strain H-6 did not diminish the titre of this serum with these strains. Strains $\mathrm{H}-1$ and $\mathrm{H}-2$ both removed antibody to

TABLE IV

Agglutination and immobilisation in agar of H-type strains of Pseudomonas aeruginosa by homologous and heterologous $H$ antisera after absorption with suspensions of heterologous strains

\begin{tabular}{|c|c|c|c|c|c|c|}
\hline \multirow{2}{*}{$\begin{array}{c}\text { Serum } \\
\text { absorbed } \\
\text { with (ab.) } \\
\text { strain }\end{array}$} & \multicolumn{6}{|c|}{$\begin{array}{l}\text { Titre of agglutination (and immobilisation) } \\
\text { by the stated absorbed serum of the type strain }\end{array}$} \\
\hline & $\mathrm{H}-\mathrm{I}$ & $\mathrm{H}-2$ & $\mathrm{H}-3$ & $\mathrm{H}-4$ & $\mathrm{H}-5$ & H-6 \\
\hline $\mathrm{H}-1$ ab. $\mathrm{H}-2$ & 3200 & - & $\cdots$ & $\cdots$ & - & $\cdots$ \\
\hline H-1 ab. H-5 & $\begin{array}{c}(1600) \\
400 \\
(200)\end{array}$ & $\begin{array}{c}\overline{400} \\
(100)\end{array}$ & $\begin{array}{l}\cdots \\
\cdots \\
\cdots\end{array}$ & $\begin{array}{l}\cdots \\
\cdots \\
\cdots\end{array}$ & $\begin{array}{l}- \\
- \\
-\end{array}$ & $\begin{array}{l}\cdots \\
\cdots \\
\cdots\end{array}$ \\
\hline H-2 ab. H-1 & - & $\begin{array}{l}1600 \\
(800)\end{array}$ & $\begin{array}{l}\ldots \\
\ldots\end{array}$ & $\begin{array}{l}\ldots \\
\ldots\end{array}$ & $\begin{array}{l}1600 \\
(800)\end{array}$ & $\begin{array}{c}200 \\
(100)\end{array}$ \\
\hline H-2 ab. H-5 & - & $\begin{array}{l}1600 \\
(800)\end{array}$ & $\ldots$ & $\ldots$ & - & $\begin{array}{c}400 \\
(100)\end{array}$ \\
\hline H-2 ab. H-6 & $\begin{array}{c}800 \\
(400)\end{array}$ & $\begin{array}{c}3200 \\
(3200)\end{array}$ & $\begin{array}{l}\cdots \\
\cdots\end{array}$ & $\begin{array}{l}\cdots \\
\cdots\end{array}$ & $\begin{array}{l}1600 \\
(800)\end{array}$ & - \\
\hline H-4 ab. H-6 & $\begin{array}{l}\cdots \\
\cdots\end{array}$ & $\ldots$ & $\begin{array}{l}\ldots \\
\cdots\end{array}$ & $\begin{array}{c}6000 \\
(3200)\end{array}$ & $\cdots$ & - \\
\hline H-5 ab. H-1 & - & - & $\cdots$ & $\begin{array}{c}800 \\
(200)\end{array}$ & $\begin{array}{c}3200 \\
(1600)\end{array}$ & $\begin{array}{c}800 \\
(400)\end{array}$ \\
\hline H-5 ab. H-2 & - & - & & $\begin{array}{c}400 \\
(200)\end{array}$ & $\begin{array}{c}3200 \\
(1600)\end{array}$ & $\begin{array}{c}400 \\
(200)\end{array}$ \\
\hline H-5 ab. H-4 & $\begin{array}{l}1600 \\
(800)\end{array}$ & $\begin{array}{l}1600 \\
(800)\end{array}$ & $\ldots$ & - & $\begin{array}{c}6400 \\
(3200)\end{array}$ & - \\
\hline H-5 ab. H-6 & $\begin{array}{l}1600 \\
(800)\end{array}$ & $\begin{array}{l}1600 \\
(800)\end{array}$ & $\cdots$ & $\begin{array}{l}- \\
-\end{array}$ & $\begin{array}{c}6400 \\
(3200)\end{array}$ & - \\
\hline H-6 ab. H-2 & $\ldots$ & - & $\ldots$ & $\begin{array}{l}1600 \\
(800)\end{array}$ & $\ldots$ & $\begin{array}{c}6400 \\
(3200)\end{array}$ \\
\hline H-6 ab. H-4 & $\ldots$ & $\begin{array}{c}400 \\
(200)\end{array}$ & $\begin{array}{l}\ldots \\
\ldots\end{array}$ & $\begin{array}{l}- \\
-\end{array}$ & $\ldots$ & $\begin{array}{r}6400 \\
(3200)\end{array}$ \\
\hline
\end{tabular}


each other from serum H-5 but not to heterologous strains H-4 and H-6. Similarly, strains $\mathrm{H}-4$ and $\mathrm{H}-6$ did not decrease the heterologous titres of serum $\mathrm{H}-5$ with strains $\mathrm{H}-1$ and $\mathrm{H}-2$.

\section{Discussion}

Many $\mathrm{H}$ antigen-typing schemes have been described for $P$. aeruginosa (Christie, 1948; van den Ende, 1952; Verder and Evans, 1961; Lányi, 1970) but the antigenic specificity of sera raised against whole unheated cells and tested by agglutination has been questioned (Liu, 1968; Sadoff, 1974; Ansorg, 1978). Ansorg (1978) used indirect immunofluorescence to visualise the flagella of $P$. aeruginosa and constructed a typing scheme based largely on the types described by Lányi (1970). This method, although accurate, is laborious for the typing of large numbers of cultures; an agglutination method, if specific, is to be preferred.

A re-examination of " $\mathrm{H}$ sera" that had been prepared against unheated whole cells (Parker et al., 1976) showed that these sera were not H specific (Pitt, 1979). Antibody to heat-labile somatic antigens was found in high titre, although titres to heat-stable antigen were low. To raise specific agglutinating sera it was necessary to eliminate the effect of these cellular antigens.

Orcutt (1924) demonstrated that an antiserum prepared against purified flagellar filaments did not agglutinate heated cells or non-flagellate variants. More recently, Aleksić and Rohde (1972) used purified flagellar antigens of salmonella-arizona strains for the preparation of high-titre diagnostic $\mathrm{H}$ sera.

McDonough (1965) found that preparations of flagellar filaments of Salmonella sp. often contained up to $10 \%$ of carbohydrate; he considered this to be due to contamination with the lipopolysaccharide $\mathrm{O}$ antigen and found that this component persisted even after acid dissociation of the flagella. My preparations of flagella of $P$. aeruginosa contained a significant amount of carbohydrate $(c .8 \%)$, and nearly all the antisera prepared against them contained a small but detectable amount of antibody to somatic antigens. The highest titres of this antibody were induced by the more concentrated flagellar suspensions.

Nossal, Ada and Austin (1964) found that a dose as small as $10 \mathrm{pg} / \mathrm{ml}$ of the flagella of Salmonella adelaide resulted in the formation of antibody in rats. The smallest dose I used was $0.025 \mu \mathrm{g}$ of protein in a preparation of flagella of $P$. aeruginosa and this induced a good agglutinin response in rats; a 100-fold increase of dose stimulated a titre only twice as great. A course of injections of rising dose (25 to $400 \mu \mathrm{g}$ ) was finally chosen for the preparation of sera in rabbits; further increase in dosage gave little improvement in $\mathrm{H}$ titres and resulted in the appearance of unacceptable amounts of $\mathrm{O}$ antibody. The peak of $\mathrm{H}$ antibody production was reached after the animal had received only four injections of antigen and sera of satisfactory titre was usually obtained within 3 weeks.

The homologous titres of agglutination and immobilisation of the six sera prepared against purified flagella of the H-type strains were high, but five of the 
sera exhibited significant cross reactions with heterologous strains. Antigen H-3 was distinct and probably represented the "uniform" antigen described by Lányi (1970) and Ansorg (1978). Cross-absorption tests revealed another two apparently distinct groups represented by the strains $\mathrm{H}-1, \mathrm{H}-2$ and $\mathrm{H}-5$, and the strains $\mathrm{H}-4$ and $\mathrm{H}-6$. These antigens may be minor factors of a "complex" group antigen (Lányi 1970; Ansorg 1978). Specific sera to each type strain were readily prepared by absorption, but some loss of homologous titre was experienced in tests with sera $\mathrm{H}-1, \mathrm{H}-2$ and $\mathrm{H}-5$. Furthermore, an additional factor associated with strains $\mathrm{H}-2$ and $\mathrm{H}-6$ and $\mathrm{H}-4$ and $\mathrm{H}-5$ was observed. This was distinguishable from the strain-specific antigen and may represent another minor $\mathrm{H}$ factor.

It can be seen from the present study that the results of agglutination and immobilisation tests confirm that the sera raised against purified flagella are $\mathrm{H}$ specific, and that $\mathrm{H}$ antigens can be distinguished with confidence by a single agglutination test.

\section{REFERENCES}

Aleksić, S. AND RoHDE, R. 1972. The separation and purification of Salmonella-Arizona $\mathrm{H}$-antigens by the DEAE-cellulose column chromatography for the preparation of diagnostic $\mathrm{H}$-antisera with high titres and free of $\mathrm{O}$-antibodies. Annls Inst. Pasteur, Paris, $123,363$.

AnsoRg, R. 1978. Flagellaspezifisches H Antigenschema von Pseudomonas aeruginosa. Zentbl. Bakt. ParasitKde, I. Abt. Orig., 242, 228.

Bergan, T. 1975. Epidemiological typing of Pseudomonas aeruginosa. In Resistance of Pseudomonas aeruginosa, edited by M. R. W. Brown, Wiley, New York, p. 189.

Bradley, D. E. 1966. The structure and infective process of a Pseudomonas aeruginosa bacteriophage containing ribonucleic acid. J. gen. Microbiol., 45, 83 .

Bradley, D. E. 1972. Stimulation of pilus formation in Pseudomonas aeruginosa by RNA bacteriophage adsorption. Biochem. biophys. Res. Commun., 47, 1080.

BradLey, D. E. 1973. Basic characterization of a Pseudomonas aeruginosa pilus-dependent bacteriophage with a long non-contractile tail. J. Virol., 12, 1139.

Bradley, D. E. AND Pitt, T. L. 1974. Pilus-dependence of four Pseudomonas aeruginosa bacteriophages with non-contractile tails. J. gen. Virol., 24, 1.

Christie, R. 1948. Observations on the biochemical and serological characteristics of Pseudomonas pyocyanea. Aust. J. exp. Biol. med. Sci., 26, 425.

ENDE, M. VAN DEN 1952. Observations on the antigenic structure of Pseudomonas aeruginosa. J. Hyg., Camb., 50, 405.

HABS, I. 1957. Untersuchungen über die O-antigene von Pseudomonas aeruginosa. Z. Hyg. InfektKrankh., 144, 218.

Holloway, B. W. 1955. Genetic recombination in Pseudomonas aeruginosa. J. gen. Microbiol., 13, 572.

Homma, J. Y., Kim, K. S., Yamada, H., Ito, M., Shionoya, H. and Kawabe, Y. 1970. Serological typing of Pseudomonas aeruginosa and its cross-infection. Jap. J. exp. Med., 40, 347.

LÁNYI, B. 1966-67. Serological properties of Pseudomonas aeruginosa. I. Group-specific somatic antigens. Acta microbiol. hung., 13, 295.

LÁNyI, B. 1970. Serological properties of Pseudomonas aeruginosa. II. Type-specific thermolabile (flagellar) antigens. Acta microbiol. hung., 17, 35.

LiNDBERG, R. B., LATTA, R., BRAME, R. AND MONCRIEFF, J. A. 1963 . Bacteriophage typing of 
Pseudomonas aeruginosa: epidemiologic observations based on type distribution. Bact. Proc., p. 72.

LiU, P. V. 1968. Analytical serology of Pseudomonadaceae. In Analytical serology of microorganisms, vol. 2, edited by I. B. G. Kwapinski, Wiley, New York, p. 1.

Lowry, O. H., Rosebrough, N. J., FarR, A. L. AND Randall, R. J. 1951. Protein measurement with the Folin phenol reagent. J. biol. Chem., 193, 265.

McDonough, M. W. 1965. Amino acid composition of antigenically distinct Salmonella flagellar proteins. J. molec. Biol., 12, 342.

Molllo, A. M. 1973. Isolation of a transducing phage forming plaques on Pseudomonas maltophilia and Pseudomonas aeruginosa. Genet. Res., 21, 287.

Nossal, G. J. V., AdA, G. L. AND Austin, C. M. 1964. Antigens in immunity. II. Immunogenic properties of flagella, polymerized flagellin and flagellin in the primary response. Aust. J. exp. Biol. med. Sci., 42, 283.

OrCuTT, M. L. 1924. The effect of heat on flagellar and somatic agglutination. J. exp. Med., 40, 627.

Parker, M. T., Pitt, T. L., Asheshov, E. H. and Martin, D. R. 1976. The selection of typing methods for Pseudomonas aeruginosa. In Proceedings of the VI international colloqium on phage typing and other laboratory methods for epidemiological surveillance, Wernigerode, GDR, 1975, Vol. 2, p. 469.

PITt, T. L. 1979. A study of the heat-labile antigens of Pseudomonas aeruginosa. Ph.D Thesis, Council for National Academic Awards, London.

Pitt, T. L. AND BRADley, D. E. 1975. The antibody response to the flagella of Pseudomonas aeruginosa. J. med. Microbiol., 8, 97.

Pitt, T. L. AND ERdman, Y. J. 1978. The specificity of agglutination reactions of Pseudomonas aeruginosa with $\mathrm{O}$ antisera. J. med. Microbiol., 11, 15.

SAdoFf, J. C. 1974. Cell-wall structures of Pseudomonas aeruginosa with immunologic significance: a brief review. J. infect. Dis., suppl., 130, S61.

Trevelyan, W. E. AND Harrison, J. S. 1952. Studies on yeast metabolism. I. Fractionation and microdetermination of cell carbohydrates. Biochem. J., 50, 298.

Verder, E. AND EVANS, J. 1961. A proposed antigenic schema for the identification of strains of Pseudomonas aeruginosa. J. infect. Dis., 109, 183. 